\title{
震災後における宮城県の子どものからだと心 〜女川町における調査と体育支援から見えた課題と希望〜
}

\author{
鈴木 宏 哉, 岡 㟝勘 造 ${ }^{2}$, 坂 本 譲 2 \\ ( ${ }^{1}$ 順天堂大学スポーツ健康科学部, ${ }^{2}$ 東北学院大学教養学部)
}

はじめに：2011年 3 月に発生した東日本大震災は, 被災 した地域，そしてその地域に住む人々だけではなく，被 災しなかった地域の在り方や人々の考え方までも大きく 変えた。震災元年に入学した小学生は卒業の年を迎え, 中学生は高校卒業をひかえている. 子どもに扔ける 5 年 間は大人のそれとは比べものにならないほど身心の発育 発達が著しい, 震災当時, 宮城県沿岸部被災地域の女川 町では「学校でこそ子どもは育つ」という遠藤定治教育 長（当時）の考元から, 宮城県内の被災した多くの小中 学校が 4 月下旬から再開した中, 4 月 12 日から再開し た. 教育復興の舵取りを行うトップの決断が子どもたち にどのような効果があったのかを検証することは容易で はないが, 我々は 2011 年 9 月から女川町の小学 4 年生 から中学 3 年生まで全児童生徒の健康・運動量等調査を 行っており, 2012年 3 月の調査以降は毎年 3 月に実施し, 2016年 3 月の調査で 6 回目となった。東日本大震災は阪 神・淡路大震災と比較されることが多いが, 例えばプレ 八ブ仮設住宅の入居者は阪神・淡路大震災では 5 年後に ゼロになったが, 東日本大震災では 3 割近くが 6 年目を 迎えてもな㧔って打り，解消の見通しの立っていない 市町村すら存在する，身心の発育発達が著しい子どもた ちにとって, 生活環境の復興が遅れているこの現状は今 に扔ける子どもの諸問題よりも, 将来に扔ける問題とし て憂慮すべき事態である，女川町に扔ける 6 年間の調査 データと教育支援から見えた課題について議論の材料を 提供したい.

生活・運動環境の変化：震災後に引っ越しを余儀なく された子どもは，2011年 9 月調査時点では，小学生で $59.4 \%$, 中学生で $51.6 \%$ であ, 仮設住宅入居者は小学 生で $52.2 \%$, 中学生で $44.7 \%$ であった。すなわち, 引っ 越しした子どものほとんどが仮設住宅への引っ越しだっ た。 そして 2016 年 3 月調査時点でも未だ仮設住宅入居者 は小学生で $28.9 \%$, 中学生で $42.1 \%$ あり, 多くの子ど もが 5 年間以上も仮設居住を強いられている.

組織的スポーツ活動への参加率の推移をみると, 小学 生では2011年 9 月調查時点では小学生で $32.0 \%$, 中学生 で64.7\%であったが, 2016年 3 月調査時点ではそれぞれ, $53.5 \%$ と $59.3 \%$ となり, 小学生に扔ける参加率の増加が 確認できた，特に小学生に扔いては女子の増加（18.8\% $\rightarrow 47.8 \%$ ）が顕著であった。 中学校においては早期に運 動部活動が再開されていたが, 運動部活動制度のない小 学校に扔いては震災当初はスポーツ少年団のような学外
での自主的な活動に委ねられていた，そこで企画した学 内での放課後遊びの取り組み（鈴木, 体育科教育11月号: 36-40, 2015）などにより（特に, 運動・スポーツを普段行っ ていない女子の）運動機会が増加したと考えられる。小 学校に㧈ける取り組みは運動しない子（体育授業を除く 1 週間総運動時間 60 分未満者）を減らすことに貢献し, 2012 年 3 月調查時に $35.5 \%$ であった運動しない子の割合 は2016年 3 月調查時には $27.6 \%$ へ減少した。

健康関連 QoL：QoL（日本語版PedsQL）に関する 2011 年 9 月から 2015 年 3 月までの 5 時点の分析結果 (中学生 データ) では, 有意な経時変化は確認されず, 女子（77.4 \pm 13.4 点）は一貫して男子（83.7 \pm 12.5 点）よりも低く, 女子の值は先行研究と比べても低い傾向にあった。 また, QoLの経年変化を運動部加入別に比較すると, 運動部加 入者の QoLは運動部未加入者と比べ高く, 2012 年調査 時点でその差が最大となり, 徐々にその差が小さくなっ た，すなわち，運動部活動はQoLに対して好影響を与え るが，その影響は時間経過とともに小さくなっているこ とが確認できた。

さいごに：「失礼な言い方かもしれないが，来ているか 来ていないか分からない支援だけども確かに学校からは 日常の一コマに関わってくれて助かっているとの声が上 がってきていたので, 大変助かった.」これは, 現女川 町教育長の言葉である，子どもと日々向き合っている教 師を支えること，そして，放課後の日常的運動環境を保 障することを目指した我々の取り組みの最もうれしい評 価であった。

学校は支援を受け入れる消極的な姿勢から，学校と子 どもを支える周辺のサポーターに協力を要請する積極的 な姿勢に変わることができる体力を取り戻しつつある。 人は人とのつながりで動くので, 学校のような人事異動 の多い組織では人事異動とともに協力者が異動すること もままある。被災地に打いても例外ではない。したがっ て, 学校を支える人材バンクの管理・運用をシステム化 することが不可欠であろう，被災地では学校（教師と子 どもを支える）環境の充実が求められ，学校を支える恒 久的仕組みを構築しておくことが, 被災地に限らず格差 を是正する方策であろう。

付記：本研究はJSPS 科研費 24680065, 26750323, 子ども の健康づくりのためのスポーツ医科学研究拠点の形成 (私 立大学戦略的研究基盤形成支援事業)の助成を受けた. 